\title{
Wound Repair
}

National Cancer Institute

\section{Source}

National Cancer Institute. Wound Repair. NCI Thesaurus. Code C17260.

Restoration of diseased or damaged tissues naturally by healing processes. 